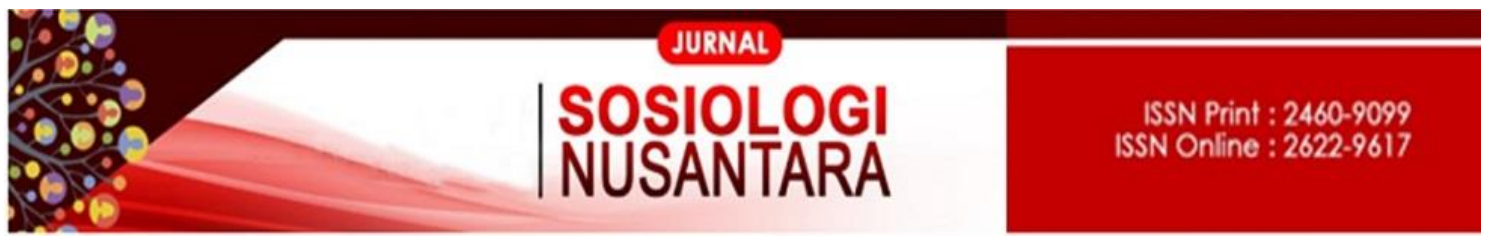

https://ejournal.unib.ac.id/index.php/jsn

DOI ://doi.org/10.33369/jsn.4.1.20-28

\title{
UPAYA DESA AIR NAPAL DALAM MENGUASAI KEMBALI LAHAN YANG TERLIBAT KONFLIK AGRARIA DENGAN PT BIO NUSANTARA TEKNOLOGI (Studi Kasus Di Desa Air Napal, Kecamatan Bang Haji, Kabupaten Bengkulu Tengah)
}

\author{
The Efforts of Villagers of Water Napal to Control Land Affected by Agrarian \\ Conflict With PT Bio Nusantara Teknologi \\ (Case Study In Napal Water Village, Bang Haji Sub-district, \\ Central Bengkulu Regency)
}

\author{
Ade Ruhiyat $^{1}$, Heri Sunaryanto ${ }^{2}$, Sumarto Widiono ${ }^{3}$ \\ hsunaryanto55@gmail.com \\ 123. Fakultas Ilmu Sosial dan Ilmu Politik, Universitas Bengkulu
}

\begin{abstract}
Abstrak
Upaya warga menguasai kembali lahan yang terlibat konflik perkebunan dengan studi kasus warga Desa Air Napal Kecamatan Bang Haji Kabupaten BengkuluTengah melawan PT Bio Nusantara Teknologi. Penelitian ini bertujuanmengetahuipenyebab mengapa konflik terjadi serta mengungkap upaya apa saja yangdilakukan warga Desa Air Napal dalam mendapatkan kembali lahan tersebut.Penyebab konflik lahan antara warga Desa Air Napal dan PT Bio NusantaraTeknologi sudah terjadi sejak tahun 1981 saat pertama kali perusahaan melakukanpembebasan hutan atau kebun warga yang akan dijadikan lahan usaha kebun kelapa sawit. Informan ditentukan melalui teknik Purposive Sampling(sampel bertujuan) dengan memilih informan kunci yang dianggap mengetahui informasi danmasalah secara mendalam serta dapat dipercaya untuk menjadi sumber data. Informan dalam penelitian ini dibagi menjadi informan inti yakni informan yang terlibat aktif dalam perlawanan dan memiliki keterkaitan lahan yangdiserobot PT Bio Nusantara Teknologi dan informan tambahan yakni informan yang memiliki keterkaitan dengan perlawanan yang dilakukan warga.Penelitian ini menggunakan metode kualitatif dengan metode pengumpulan data berupainterview, observasi dan telaah dokumen yang dapat menggambarkan secara rinciupaya-upaya yang dilakukan warga Desa Air Napal. Teori konflik yang dikemukan oleh Ralf Dahredorf menjadi alat bantu analisis masalah dan telaah data penelitian. Penelitian ini memberikan informasi bahwa ada dua cara yang dilakukan warga sebagai upaya menguasai kembali lahan tersebut, yakni cara terbuka dan tersembunyi. Cara terbuka seperti membentuk organisasi perlawananForum Masyarakat Sungai Lemau Bersatu (FMSLB), aksi demontrasi, hearing bersama Pemda dan DPRD, cara ini ditempuh
\end{abstract}


warga dengan harapan banyak pihak terlibat maka konflik segera diakhiri. Cara tersembunyi seperti mendesakstake holder, meminta advokasi, mengirim surat dan meminta perlindunganKomnas HAM juga dilakukan warga setelah cara terbuka tidak membuahkan hasil optimal.

Kata Kunci: Relasi Kerja Asimetris, Mandor, dan Buruh Pemetik Teh

\begin{abstract}
Efforts residents take control of land affected by plantation conflicts with a case study of villagers Air Napal District Bang Haji Bengkulu Tengah District against PT Bio Nusantara Technology. This study aims to determine the causes of why the conflict occurred and reveal what efforts are made Watermal Village villagers in getting back the land. The cause of land conflicts between the villagers of the water of napal and PT Bio Nusantara Teknologi has occurred since 1981 when the first time the company did the forest clearance or the garden of the citizens to be used as the palm oil plantation business. The informant is determined by Purposive Sampling technique (purposive sampling) by selecting the key informant who is considered to know the information and problem deeply and can be trusted to become the data source. Informants in this study were divided into core informants ie informants who are actively involved in the resistance and have a linkage of land that was snatched by PT Bio Nusantara Teknologi and additional informants ie informants that have links with the resistance made by citizens. This study uses qualitative methods with data collection methods in the form of interviews, observation and document review that can describe in detail the efforts made by the villagers of Air Napal. Ralf Dahredorf's theory of conflict is a tool for problem analysis and study of research data. This research provides information that there are two ways that citizens do as an effort to control the land, the way open and hidden. Open methods such as forming an insurgency organization of Lemau Unity River Community Forum (FMSLB), demonstration action, hearing with local government and DPRD, this way taken by citizens with the hope of many parties involved then the conflict immediately ended. Hidden ways such as urging stakeholders, asking for advocacy, sending letters and requesting protection of Komnas HAM are also conducted by residents after the open manner does not produce optimal results.
\end{abstract}

Keywords: Land Conflict Plantation

\title{
PENDAHULUAN
}

Lahan atau tanah merupakan sesuatu yang sangat penting untuk dikuasai atau dimiliki, sebab dengan adanya lahan maka seseorang bisa mendirikan rumah, tempat usaha dan berbagai hal lainnya yang akan berpengaruh pada hidup seseorang ke depannya. Bertambahnya jumlah penduduk setiap tahunnya menjadikan kebutuhan akan lahan untuk bermukim dan berusaha semakin meningkat, sehingga menjadikan tanah atau lahan memiliki nilai ekonomi yang tinggi. Di sisi lain, pertambahan jumlah penduduk juga menyebabkan lahan menyempit dan semakin terbatas, sebab itulah sering kali kepemilikan atau penguasaan lahan menimbulkan konflik atau sering 
disebut sebagai konflik agraria, baik antar warga sipil, warga dengan perusahaan swasta maupun warga sipil dengan negara. Konflik agraria atau sengketa lahan antara warga sipil dengan perusahaan-perusahaan besar, khususnya yang bergerak di sektor perkebunan dan tambang di Indonesia terus menujukan angka meningkat setiap tahunnya. Akibatnya, bukan saja kegiatan poduksi pihak perusahaan menjadi terganggu, namun masyarakat sipil juga kehilangan akses dalam mengelola lahan yang mereka warisi dalam keluarga secara turun temurun.

Kebijakan pemerintah baik pusat maupun daerah ikut menyumbang terjadinya konflik antara warga sipil dengan pihak perusahaan, salah satunya adalah kebijakan pemerintah yang dengan mudah mengeluarkan izin penguasaan lahan dalam kurun waktu yang sangat lama, seperti Hak Guna Usaha (HGU) dan izin eksplorasi atas lahan tersebut. Akibatnya, lahan usaha yang selama ini dikuasai masyarakat diambil alih perusahaan, Lembaga Research Centre For Crisis And Alternative Development Strategy, Inkrispena merilis kasus konflik agraria di Indonesia yang disebabkan oleh kebijakan pejabat publik dan berdampak secara luas baik dari sisi sosial, politik, ekonomi dan budaya sejak tahun 2009 hingga 2014 meningkat $430 \%$.

Tingginya angka kasus konflik di Indonesia tersebut berbanding lurus dengan meningkatnya luas wilayah konflik setiap tahunnya, yakni meningkat $2.046 \%$ sejak tahun 2009 hingga 2014. Pada tahun 2009, Inkrispena mencatat ada 89 kasus konflik agraria dengan luas areal konflik seluas 133.278 hektare, kemudian pada 2010 menjadi 106 kasus dengan luas areal konflik 167.741 hektare. Di tahun 2011 kembali meningkat menjadi 163 kasus dengan luas areal konflik meningkat tajam yakni mencapai 472.028 hektare. Di tahun 2012 menjadi 198 kasus dengan luas areal lahan meningkat menjadi 963.411 hektare, pada tahun 2013 melonjak menjadi 369 kasus dengan luas lahan konflik mencapai 1.281.660 hektare dan pada akhir tahun 2014 tercatat ada 475 kasus konflik dengan luas areal konflik mencapai 2.860.977.

Berikut gambaran peningkatan kasus dan luas areal konflik agraria yang diolah dari data Inkrispena sejak tahun 2009-2014.Khusus di Kabupaten Bengkulu Tengah (Benteng), sedikitnya sejak 2008 hingga 2014 terjadi 2 kali sengketa lahan waga melawan perusahaan perkebunan swasta, yakni di tahun 2011, warga 20 desa dari 3 Kecamatan melawan PT Bio Nusantara Teknologi (BNT) dan di tahun 2012 warga melawan PT Agri Andalas. Namun keduanya memiliki latar yang berbeda, jika di kasus 
sengketa pada tahun 2011 warga melawan karena adanya upaya penyerobotan lahan warga oleh perusahaan, yang akhirnya membuka sejarah lama dan menyebabkan konflik baru terkait lahan HGU yang dikuasai PT Bio Nusantara Teknologi, sedangkan di tahun 2012 konflik terjadi lantaran warga pendatang di Desa Dusun Anyar Kecamatan Pondok Kubang menggarap lahan yang masuk dalam peta HGU milik PT Agri Andalas.

Konflik agraria warga 20 desa yang tersebar di Kecamatan Bang Haji, Pematang Tiga, Pondok Kelapa itu menuntut pengembalian lahan mereka seluas 117 hektare dari 6000 hektare yang saat ini dikuasai perusahaan perkebunan kelapa sawit, PT. Bio Nusantara Teknologi melalui hak guna usaha (HGU). Bahkan konflik lahan itu juga sempat menyulut emosi warga dengan membakar aset perusahaan dan berujung pada aksi penangkapan warga oleh aparat keamanan. Aksi pembakaran tersebut lantaran warga kesal tak mendapatkan kepastian pengembalian lahan mereka dan adanya aksi penanaman kelapa sawit oleh pihak perusahaan di wilayah yang sudah ditetapkan sebagai lahan warga.

Fokus masalah dalam penelitian ini pada penghimpunan data terkait penyebab konflik dan upaya apa saja yang dilakukan warga Desa Air Napal untuk mendapatkan kembali lahan mereka yang diklaim PT Bio Nusantara Teknologi masuk dalam HGU. Tujuan dari penelitian ini adalah untuk mengetahui penyebab mengapa konflik terjadi serta mengungkap upayaapa saja yang dilakukan warga Desa Air Napal dalam mendapatkan kembali lahan tersebut. Teori yang digunakan adalah teori konflik yang dikemukan oleh Rafl Dahredorf. Teori ini muncul sebagai reaksi atas teori fungsionalisme structural yang kurang memperhatikan fenomena konflik dalam masyarakat. Teori ini memandang masyarakat sebagai sistem sosial yang terdiri atas kepentingan-kepentingan yang berbeda-beda dimana ada suatu usaha untuk menaklukan komponen yang lain.

\section{METODE PENELITIAN}

Dalam melakukan penelitian yang mengupas penyebab konflik dan upaya warga Desa Air Napal mendapatkan kembali lahan, peneliti menggunakan pendekatan metode kualitatif dengan analisis Studi Kasus(case study).Penelitian ini menggunakan metode penelitian kualitatif dan dilakukan di desa Air Napal Kecamatan Bang Haji Kabupaten 
Bengkulu Tengah,dengan alasan warga desa ini merupakan warga yang paling banyak melakukan perlawanan dan upaya merebut kembali lahan HGU yang dikuasai PT Bio NusantaraTeknologi. Warga desa ini mengklaim lahan HGU seluas 50 hektare dari 6000 hektar total luas HGU PT Bio Nusantara Teknologi merupakan wilayah desa, sebab sebelumnya lahan 50 hektare yang berbatasan langsung dengan desa itu pernah didiami $25 \mathrm{KK}$ dan terdapat 46 makam warga serta menjadi cikal bakal Desa Air Napal saat ini. Akibat adanya HGU itu maka $25 \mathrm{KK}$ itu terpaksa pindah ke tepi sungai Air Napal dan meninggalkan lahan garapan, makam keluarga dan rumah mereka yang diklaim PT Bio Nusantara Teknologi masuk dalam HGU yang mereka dapatkan.

Metode pengumpulan data yang digunakan dalam penelitian ini yakni data primer dan sekunder dengan menggunakan metode observasi, wawancara. Informan peneliti tentukan dengan teknik Purposive Sampling (sampel bertujuan), yakni informan dipilih sesuai dengan kriteria yang ditentukan. Teknik analisis data yang digunakan yakni tahap uji keabsahan data (teknik Triangulasi, yakni membandingkan keadaan dan prespektif informan dengan berbagai pendapat dan perspektif orang lain melalui informan tambahan dan tahap penyimpulan.

\section{PEMBAHASAN}

\section{Penyebab Konflik Dan Upaya Warga Mendapatkan Kembali Lahan}

\section{Penyebab Konflik}

Konflik lahan antara warga dan PT BNT sudah terjadi sejak tahun 1981 saat pertama kali pihak perusahaan melakukan pembabasan hutan dan penyerobotan lahan atau kebun warga yang akan dijadikan lahan usaha kebun kelapa sawit. Kemudian lamanya penerbitan HGU oleh pemerintah juga menjadi titik lemah bagi pihak perusahaan, sehingga warga menyebut pihak perusahaan telah melakukan kebohongan publik, selanjutnya adalah aksi perusahaan melakukan penanaman kelapa sawit di wilayah warga (dalam patok biru).

a. Penyerobotan Lahan

Konflik atau sengketa lahan antara warga Desa Air Napal melawan PT Bio Nusantara Teknologi (BNT) mencapai puncaknya pada tahun 2012. Konflik itu bermula dari penyerobotan lahan masyarakat oleh PT BNT yang membangun perkebunan kelapa sawit seluas 6.000 hektar pada tahun 1981. Lahan yang diambil PT 
25 I Ade Ruhiyat ${ }^{1}$, Heri Sunaryanto ${ }^{2}$, Sumarto Widiono ${ }^{3}$

Upaya Desa Air Napal Dalam Menguasai Kembali Lahan Yang Terlibat Konflik Agraria

BNT merupakan lahan garapan milik masyarakat di 20 desa yang tersebar di Kecamatan Bang Haji, Pondok Kelapa, Pematang Tiga dan Pagar Jati. Pengambilan lahan itu ditentang keras warga yang telah menggarap lebih dulu. Apalagi lahan yang dikuasai warga merupakan lahan yang mereka warisi secara turun temurun melalui garis keturunan keluarga atau sering disebut tanah ulayat.

b. Pembohongan Terbitnya HGU

Pihak perusahaan berdalih bahwa lahan yang saat itu dikuasai dan digarap warga merupakan tanah negara dan telah dikuasai oleh perusahaan melalui sertifikat HGU. Hanya saja, belakangan diketahui bila sertifikat HGU Nomor 421/HGU/BPN 1997 yang dipegang PT BNT justru diterbitkan pada tahun 1997, bukan tahun 1981, halini membuat warga merasa dibohongi. Selain itu, pembukaan dan perluasan lahan yang dilakukan tanpa proses ganti rugi lahan serta adanya tindak kekerasan terhadapwarga di masa lalu kembali membuat warga bergolak.

c. Penanaman Kelapa Sawit di Luar Patok Biru

Patok biru merupakan tanda perbatasan lahan yang dikuasai PT BNT dan lahan yang dikuasai masyarakat. Setiap perbatasan kawasan dipasang patok biru sebagai tanda batas wilayah. Pihak perusahaan tak boleh menggarap lahan di luar patok biru, begitu juga masyarakat tak boleh membuka atau menggarap lahan yang masuk dalam patok biru perusahaan.

\section{d. Cemari Lingkungan}

Penurunan kualitas air sungai Lemau, penurunan kualitas udara dan penurunan debit air sumur juga menjadi persoalan warga atas aktivitas produksi PT BNT. Bahkan dari studi yang dilakukan Walhi diketahui bahwa meskipun PT BNT telah mengantongi izin UPL-UKL tertanggal 19 Agustus 1999 namun dalam menjalankan kegiatan perkebunan kelapa sawit belum 100\% menjalankan ketentuan dalam dokumen lingkungan hidup.

\section{e. Peta Konflik}

Dari uraian di atas maka dapat diuraikan peta konflik antara warga Desa Air Napal dengan PT BNT, yakni sebagai berikut, Desa Air Napal Kecamatan Bang Haji Kabupaten Bengkulu Tengah sejak awal merupakan desa marga yang sudah ada sejak zaman kolonial dengan penduduk bersuku Rejang. Warga desa ni menggantungkan hidup dengan bertani dan berkebun kopi, karet dan beberapa lahan juga digarap sebagai 
ladang atau sawah darat, sebab itulah warga Desa Air Napal menyebut desa dan lahan di sekitar sebagai tanah adat. Selain memiliki rumah di desa, warga desa itu juga membuat talang atau pondok-pondok kecil yang menjadi tempat bermukim sementara saat menggarap dan menunggu hasil panen di kebun maupun di lahan garapan. Bahkan talang yang cukup banyak dihuni oleh warga menjadi dusun atau bagian dari Desa Air Napal yang disebut Dusun Penyeberang Batu. Dusun ini telah memiliki tempat pemakaman sendiri yang terpisah dari tempat pemakaman yang ada di tepi Desa Air Napal.

\section{KESIMPULAN}

Konflik antara warga Desa Air Napal dan PT BNT terjadi akibat adanya penyerobotan lahan garapan warga atas dasar izin prinsip yang dipegang oleh PT BNT. Warga yang merasa memiliki lahan secara turun temurun menolak memberikan lahan itu begitu saja pada perusahaan, sehingga terjadilah kegiatan intimidasi dari pihak korporasi pada warga yang menguasai lahan tersebut sebelumnya. Adanya kebohongan yang disampaikan perusahaan pada warga atas nama HGU juga menjadi kemarahan warga, sejak awal tahun 1981 pihak perusahaan mengatasnamakan HGU untuk menguasai lahan, sementara HGU perusahaan tersebut baru diterbitkan pada tahun 1997.

Warga yang tak terima lahan mereka dicaplok melakukan berbagai perlawanan. Awalnya perlawanan dilakukan secara individu namun tak efektif, warga justru banyak diintimidasi, diteror dan dipenjara. Sadar gerakan individu tak maksimal maka warga sepakat membentuk organisasi sebagai wadah gerakan mereka. Berbagai perlawanan mulai dilakukan baik secara terang-terangan maupun sembunyi-sembunyi dalam rangka merebut kembali lahan tersebut. Tak hanya itu, mereka juga meminta bantuan advokasi pada Wahalni dan Yayasan Ulayat Bengkulu sebagai pendamping di bidang hukum dan gerakan. Berbagai upaya merebut kembali lahan itu telah dilakukan warga, seperti demontrasi, hearing bersama stake holder, mengirimkan surat pada DPR RI, meminta perlindungan dari Yankomas dan Komnas HAM. Hanya saja beberapa upaya tersebut hingga saat ini (2017) belummembuahkan hasil. Ini lantaran putusnya informasi pada kalangan stake holder karena adanya Pemilu 2014 serta adanya beberapa warga yang terpenjarakan. Hanya saja metode yang digunakan tidak lagi dilakukan dengan metode 
27 I Ade Ruhiyat ${ }^{1}$, Heri Sunaryanto ${ }^{2}$, Sumarto Widiono ${ }^{3}$

Upaya Desa Air Napal Dalam Menguasai Kembali Lahan Yang Terlibat Konflik Agraria

konflik terbuka dengan melakukan demontrasi dan konfrontasi. Warga justru memilih upaya-upaya terjadinya konsensus antara mereka dengan stake holder, dengan harapan para pengambil kebijakan tak lagi memperpanjang HGU yang habis pada tahun 2025.

Saran yang diberikan yakni berupa (1) Pemerintah harus sigap menyikapi konflik ini, jika tak dituntaskan segera maka akan menjadi potensi konflik lebih besar. HGU sebagai sumber masalah diharapkan tak diperpanjang saat masa berlakunya habis. Sehingga warga bisa mendapatkan kembali lahan mereka sebagai lahan bercocok tanam untuk memenuhi kebutuhan ekonomi warga. (2) Para stake holder hendaknya mendorong proses penuntasan konflik dituntaskan segera. Terlebih desakan ekonomi menyebabkan warga kehilangan akses lahan garapan. Sementara lahan di sekitar desa sudah menjadi HGU dan dikuasai PT BNT. Kondisi ini menyebabkan warga semakin sulit di bidang ekonomi. (3) Pemerintah hendaknya lebih selektif dalam mengeluarkan perizinan. Sebelum menerbitkan perizinan, sebaiknya dilakukan studi, kajian akademik terhadap dampak dan juga dilakukan survey secara real, sehingga izin yang diberikan pada perusahaan tidak direkayasa dan bisa mendatangkan manfaat bagi warga sekitar, bukan justru membuat warga sekitar sengsara.

\section{DAFTAR PUSTAKA}

Agger, Ben. 2003. Teori Sosial Kritis: Kritik, Penerapan, dan Implikasiny. Yogyakarta: Kreasi Wacana.

Arikunto. 2010. Prosedur Penelitian. Jakarta: Rineka Cipta.

Basrowi dan Sukidin. 2002. Metode Penelitian Perspektif Mikro: Grounded theory Fenomenologi, Etnometodologi, Etnografi, Dramaturgi, Interaksi Simbolik, Hermeneutik, Konstruksi Sosial, Analisis Wacana, dan Metodologi Refleksi. Surabaya: Insan Cendekia.

Bogdan dan Taylor. 1993. Introduction to Qualitative Research Methods A Phenomenological Approach to The Social Sciences. Surabaya: Usaha Nasional.

Bungin, Burhan. 2011. Analisis Data Penelitian Kualitatif. Jakarta: Rajawali Press.

Cohen, Bruce J. 2003. Sosiologi Suatu Pengantar. Jakarta: Asdi Mahasatya.

Dwi, Kristanto Erwin. 2011. Aksi Melawan Imperium Modal. Yogyakarta: Resist Book. 
Fauzan, Hidayat Muhammad. 2004. Bentuk-bentuk Penyelesaian Konflik Reclaming dan Pendudukan Tanah Dilihat Dari Hukum Tanah Nasional (Studi Kasus Penyelesian Konflik Reclaming dan Pendudukan Tanah Antara PT Agri Andalas, PTPN VII dengan Masyarakat Desa Tanah Abang Kecamatan Talo Kabupaten Seluma, Provinsi Bengkulu). Thesis. Semarang: Universitas Diponegoro.

Fauzi, Noer. 2008. Dari Okupasi Tanah Menuju Pembaharuan Agraria. Jakarta: Rajawali Press.

Francis, Diana. 2006. Teori Dasar Transformasi Konflik Sosial. Yogyakarta: Quills.

Handoko, Widhi. 2014. Kebijakan Hukum Pertanahan. Yogyakarta: Thafa Media.

Hatta, Muhammad. 2005. Hukum Tanah Nasional dalam Perspektif Negara Kesatuan. Yogyakarta: Media Abdi.

Hiroyoshi, Kano.1997. Tanah dan Pajak, Hak Milik dan Sengketa Agraria. Jakarta: Pustaka Sinar Harapan.

Husaini. 2011. Gerakan Rakyat Bangkit. Yogyakarta: Resist Book.

Kholifah, Anisah Nur. 2014. Penguasaan Tanah dan Hubungan Antara Perusahaan Perkebunan, Masyarakat dan Pemerintah: Konflik antara Masyarakat Adat di Desa Niur dengan Perusahaan Perkebunan Karet PTPN VII Padang Pelawi, Kecamatan Sukaraja, Kabupaten Seluma. Skripsi. Bengkulu: Universitas Bengkulu.

Limbong, Bernhard. 2012. Konflik Pertanahan. Jakarta: Rafi Maju Mandiri.

Lyon, Margo L. 2008. Dasar-Dasar Konflik di Daerah Pedesaan Jawa. Jakarta: Yayasan Obor.

Peter. 2003. Teori-Teori Sosial: Observasi Kritis Terhadap Para Filsof Terkemuka. Yogyakarta: Pustaka Belajar. 